\title{
Komparácia slovenských a českých školských klubov (družín) s vybranými krajinami ${ }^{1}$
}

\author{
Michaela Minárechová, Zuzana Bánovčanová \\ Trnavská univerzita v Trnave, Pedagogická fakulta, Katedra školskej pedagogiky
}

Redakci zasláno 20.11. 2015 / upravená verze obdržena 16. 4. 2016 /

k uveřejnění přijato 27. 4. 2016

\begin{abstract}
Abstrakt: Predkladaný príspevok v prvej časti reflektuje problematiku pedagogiky volného času, ktorá je aj v súčasnosti nie presne vymedzenou a ujasnenou oblast'ou samotnej pedagogiky. Hlavným cielom príspevku je opísat' základné znaky zariadení venujúcich sa starostlivosti mimo vyučovania a porovnat' naše (české a slovenské školské kluby detí a školské družiny) zariadenia s podobnými zariadeniami v anglicky hovoriacich krajinách. $V$ d’alšej časti preto príspevok porovnáva školské zariadenia zabezpečujúce starostlivost' o deti v čase mimo vyučovania vo vybraných krajinách (UK - Anglicko, USA - Michigan) so slovenskými a českými školskými zariadeniami (realizované činnosti, časová a priestorová organizácia). Okrem objasnenia základnej terminológie spojenej s uvedenými zariadeniami sa príspevok sústreduje aj na nariadenia a požiadavky, ktoré sú na ne kladené zo strany jednotlivých štátov. Aj napriek malým variáciám zariadení, môžeme konštatovat', že ich význam a potreba má celospoločenský charakter. Najmä v našom prostredí považujeme porovnávané školské zariadenia za komplexnejšiu a praktickejšiu starostlivost' o deti v čase mimo vyučovania. Naproti tomu v zahraničí je zase viditel'nejší rozmach súkromnej sféry v oblasti pedagogiky vol'ného času a v podobných zariadeniach starostlivosti o deti $\mathrm{v}$ čase mimo vyučovania.
\end{abstract}

Kl'účové slová: komparácia, školské družiny, školské kluby detí, starostlivost’ o deti $\mathrm{v}$ čase mimo vyučovania

Starostlivost' o deti v čase mimo vyučovania je otázkou nie len pedagogiky, konkrétnejšie pedagogiky vol'ného času, ale je aj spoločenskou otázkou. V našom (slovenskom a českom) prostredí sa táto starostlivost' vyvíjala dlhé obdobie podobne. Orientácia starostlivosti o deti v čase mimo vyučovania bola a aj v súčasnosti je skôr na výchovné aspekty, avšak je prepojená aj so vzdelávacími ciel'mi.

1 Príspevok je súčastou riešenia projektu VEGA 1/0057/1511 Expertský diskurz ako zdroj komparácie kurikulárneho projektovania vzdelávania $v$ ranom detstve. 
V našom príspevku sa budeme zameriavat' na zariadenia, ktoré poskytujú starostlivost' pre deti mladšieho školského veku. Zvolili sme porovnávanie takýchto zariadení so slovenským školským klubom detí (ŠKD) a s českou školskou družinou (ŠD). Kontext (historický, ale aj obsahový) oboch zariadení ŠKD a ŠD je vel'mi podobný, vychádza zo spoločnej histórie oboch štátov, a snaha o mimotriednu (neskôr mimoškolskú) starostlivost' o deti a mládež vychádzala z rovnakých pohnútok a v čase spoločného štátu Čechov a Slovákov.

Tento kontext porovnávame s anglicky hovoriacimi krajinami, ktoré neboli ovplyvnené rovnakou politickou ideológiou. Otvára sa tu tak otázka, ako a či vôbec je organizácia a charakter mimoškolských zariadení v takto odlišných priestoroch už v súčasnosti podobná, alebo stále ostáva rozdielna.

\section{1 Školské kluby a družiny}

Pedagogika vol'ného času sa v súčasnosti v českom i slovenskom prostredí chápe najmä ako jedna z disciplín pedagogiky s rozvíjajúcim sa výskumom (Bauman, 2012), napriek tomu sa dá povedat', že pedagogika vol'ného času nadväzuje na predchádzajúce označenie „mimoškolskej výchovy“ (Kaplánek, 2010). V súčasnosti sa v našom prostredí uberá pedagogika vol'ného času rôznymi smermi skúmania a teoretizovania. $\mathrm{V}$ predkladanom príspevku však nadväzujeme na prúd pedagogiky vol'ného času, ktorá vychádza skôr z metodickej línie mimoškolskej a mimotriednej výchovy vo vol'nom čase. Táto je u nás tradične zastupovaná charakteristickými zariadeniami, ktorých ekvivalenty existujú rovnako aj v zahraničí.

Školský klub detí (predtým označovaný ako družiny mládeže a školské družiny) patrí v Slovenskej republike (d’alej už len SR) medzi školské zariadenia, ktoré zabezpečujú výchovu a vzdelávanie detí mimo vyučovania (zákon č. 265/2008 Z. z. SR, Ministerstvo vnútra Slovenskej republiky, 2008). Zariadenia, ktoré sa podielajú na výchove vo vol'nom čase sú v Českej republike (d’alej už len ČR) definované v školskom zákone č. 561/2004 Sb. (Ministerstvo školství, mládeže a tělovýchovy ČR, 2004). Poslanie jednotlivých zariadení určujú príslušné vyhlášky (napr. v ČR č. 74/2005 Sb., o zájmovém vzdělávání, Ministerstvo školství, mládeže a tělovýchovy ČR, 2005; v SR č. 306/2009 o školskom klube detí, školskom stredisku záujmovej činnosti, centre vol'ného času, školskom hospodárstve a stredisku odbornej praxe, Ministerstvo školstva, vedy, výskumu a športu SR, 2009). Do systému 
školských výchovných zariadení v ČR patria školské zariadenia pre záujmové vzdelávanie, ${ }^{2}$ medzi ktoré patria školské kluby, školské družiny a strediská vol'ného času.

Činnost', funkcie a zameranie školského klubu detí (ŠKD) sa len málo menia v závislosti od aktuálnej doby, situácie, kontextu a prostredia. Už niekol'ko desat'ročí fungujú školské kluby detí a školské družiny (ŠD) s malými obmenami ako zariadenia výchovného a vol'nočasového charakteru. Ich organizácia je $\mathrm{v}$ premenách času takmer nemenná, čo dokazujú aj mnohé zdroje z 50.-80. rokov 20. storočia (napr. Podešva, 1952; Velikanič, 1958; Dedeková et al., 1960). Vyvstáva tu však otázka, či ich význam a poslanie sú také jednoznačné a pozitívne, že nie je potrebné vyvíjat' žiadnu diskusiu o tejto problematike, alebo je tu priestor na zamyslenie sa nad zmenou ich významu a poslania.

Rovnako ako na Slovensku a v Čechách, aj v zahraničí môžeme nájst' rôzne zariadenia, ktoré sa venujú starostlivosti o deti v čase mimo vyučovania. Kladieme si otázku, či sú tieto zariadenia porovnatel'né s našimi školskými klubmi a družinami. Ich prvotné zameranie sa na mladší a starší školský vek a starostlivost' o deti v čase mimo vyučovania na prvý pohl'ad poukazujú na značnú podobnost'.

Ako sme už vyššie uviedli, desat'ročia nemenná štruktúra indikuje stereotypné predstavy a rovnako aj postupy vychovávatelov v týchto zariadeniach. Príkladom narušenia zaužívaného postupu je súčasná situácia na Slovensku. V súčasnosti sa v SR záujmová činnost' v ŠKD nerealizuje (podla zákona č. 324/2012 Z. z.). Túto činnost’ zabezpečujú centrá vol'ného času. Odsek 35 §114 uvedeného zákona mení hlavný predmet činnosti ŠKD, pričom dopĺn̆a, že činnost', ktorú zabezpečuje ŠKD, nie je totožná s činnost'ou zabezpečovanou centrom vol'ného času. Táto, na prvý pohl'ad malá zmena, prináša značný chaos v plánovaní činností a celkového obsahu vzdelávania. Navyše mnohé zo ŠKD na Slovensku túto zmenu nereflektujú, prípadne ju prehliadajú a pokračujú v zaužívanom spôsobe plánovania. ${ }^{3}$

2 Podobne ako na Slovensku, tak aj v ČR sa vo vyhláškach a zákonoch o výchove a vzdelávaní píše len o vzdelávaní, pričom tento pojem zastrešuje rovnako výchovu ako vzdelávanie.

3 Pozri bližšie Správu školskej inšpekcie o stave zabezpečenia podmienok a priebehu výchovnovzdelávacej činnosti v školskom klube detí v školskom roku 2014/2015 v SR (Štátna školská inšpekcia, 2015). 
Z vyššie uvedených dôvodov sme sa rozhodli porovnat' slovenské ŠKD a české ŠD s d'alšími podobnými zariadeniami v anglicky hovoriacich krajinách (USA a UK), čo by mohlo priniest' nové inšpirácie aplikovatel'né do nášho prostredia. Naším cielom je teda opísat' základné znaky zariadení v uvedených krajinách a následne ich porovnat's českými a slovenskými školskými klubmi (družinami), výsledkom čoho bude očakávaný súpis možných podobností i špecifík jednotlivých zariadení. Ďalším cielom je priniest’ novú perspektívu a inšpiráciu pre možnú zmenu v tejto oblasti, prípadne potvrdit' legitimitu dlhoročne sa nemeniacej štruktúry našich vol'nočasových (mimoškolských) zariadení.

Školské družiny a školské kluby patria podl’a Pávkovej a kol. (2008) k základným formám výchovy mimo vyučovania a starostlivosti o deti zamestnaných rodičov v priebehu školského roka, podla potreby aj počas prázdnin. Školská družina je určená pre žiakov 1.-5. ročníka základnej školy a školský klub je určený pre žiakov 6.-9. ročníka. V ČR je tak starostlivost' o žiakov zabezpečovaná počas celej dochádzky žiaka do základnej školy. Podla vtedajších údajov uvádzajú autori, že počet školských družín je väčší ako počet školských klubov. Táto skutočnost' vyplýva z celkového zamerania jednotlivých zariadení. ŠKD na Slovensku, svojím poslaním a zameraním, takisto vekovou skupinou detí a žiakov, zodpovedá v ČR školskej družine (ŠD). Tento názov sa v minulosti uplatňoval aj na Slovensku a v súčasnosti je používaný laickou verejnost'ou (najmä starými rodičmi, ale aj rodičmi) na označenie ŠKD. Na Slovensku je mimoškolská starostlivost' o deti zameraná len na žiakov 1.-5. ročníka základnej školy. Rovnako aj starostlivost’ o tieto deti vychádza zo základného predpokladu, že rodičia detí, navštevujúcich ŠKD, pracujú. Tieto zariadenia sú zriad'ované pri základných školách, ale môžu vznikat' aj samostatne, pričom môžu slúžit' jednej ale aj viacerým školám.

\section{Starostlivost' o deti v čase mimo vyučovania}

Pred samotným charakterizovaním jednotlivých zariadení považujeme za nutné objasnit’ základný pojem, s ktorým pracujeme v príspevku, a tým je starostlivost' o deti v čase mimo vyučovania. Podl'a Smith a Barker (2000) tento pojem predstavuje starostlivost' o deti, ktorá sa uskutočňuje v čase po vyučovaní a počas školských prázdnin v prostredí, ktoré ponúka príležitost' na kreatívne a zábavné trávenie času. V súčasnosti podla Kratochvílovej (2010) v česko-slovenskom kontexte hovoríme v rámci pedagogiky vol'ného 
času o výchove vo vol'nom čase, ktorú možno charakterizovat' ako „cielavedomú, zámernú, organizovanú činnost’ zameranú na formovanie a rozvoj osobnosti, ktorú uskutočňujú školské i mimoškolské inštitúcie, zariadenia, organizácie, občianske združenia (teda $\mathrm{v}$ školskom i mimoškolskom systéme) s det'mi a mládežou v ich vol'nom čase" (s. 20). Kratochvílovej definícia a pojem výchovy vo volnom čase sú ovela širšie, ako je zameranie nášho príspevku.

I ked' v niektorých krajinách prevláda v tejto oblasti súkromný sektor, v našom príspevku sa budeme venovat' (najmä kvôli komparácii s našimi ŠKD a českými ŠD) zariadeniam, ktoré spravuje škola - podla Kratochvílovej sú to školské inštitúcie zabezpečujúce výchovu vo vol'nom čase. Historický aspekt (nielen) nášho prostredia ukazuje, že výchova vo vol'nom čase bola vždy spojená s povinnostou (protiklad vol'ného času a povinnosti) - a to školopovinnostou. Pri realizovaní komparácie týchto zariadení vo vybraných krajinách sme sa preto zamerali na zariadenia, ktoré majú charakter našich školských zariadení, t.j. kombinácie školského vzdelávania s využitím služieb starostlivosti o deti vo vol'nom čase. Aby bola zachovaná istá paralela pri porovnávaní našich a zahraničných zariadení zabezpečujúcich výchovu v čase mimo vyučovania, vyberali sme zariadenia pod štátnym dohladom.

Služby, ktoré poskytujú takéto zariadenia u nás aj v zahraničí, vyhl’adávajú najmä zamestnaní rodičia (na plný/polovičný úväzok), ktorí žijú sami (bez partnera, otca/matky diet’ata), alebo rodičia, ktorí ešte študujú. Ide najmä o deti v predškolskom a mladšom školskom veku. Dôvody dopytu po týchto zariadeniach najčastejšie súvisia s:

- Prácou rodičov - takmer dve tretiny detí školského veku a mládeže žije $\mathrm{s}$ jedným alebo oboma zamestnanými rodičmi (U. S. Office of personnel management, 2015).

- Vhodným prostredím pre deti - deti, ktoré nie sú pod dohladom dospelej osoby v čase mimo vyučovania, sú vystavené omnoho väčšiemu riziku záškoláctva, stresu, zhoršeného prospechu či nežiaduceho správania sa. Naopak deti, ktoré navštevujú školské kluby, majú omnoho lepšie vztahy s rovesníkmi, sú emočne vyrovnané, vedia lepšie riešit' konflikty, a pod. (U. S. Office of personnel management, 2015).

V súčasnej dobe ŠKD a ŠD predstavujú pre deti bezpečné miesto, v ktorom sú deti pod dohladom skúsených odborných pracovníkov - vychovávatelov. 
Rodičom (prednostne rodičom pracujúcim a rodičom samoživitelom) je tak štátom zabezpečovaná formálna starostlivost' o deti. V súčasnosti je na Slovensku trend rozširovania a dotovania materských škôl pre rýchlo rastúci počet detí. Logickým dôsledkom tohto trendu je v najbližších rokoch aj nárast dopytu po zariadeniach zabezpečujúcich starostlivost’ o školopovinné deti v čase mimo vyučovania.

V minulosti bol rodinný stav žien najdôležitejším ukazovatel'om ich ekonomickej činnosti. Avšak v súčasnosti sa dôležitejším determinantom stáva to, či sú ženy s det'mi zamestnané, alebo nie (Callender, 2000). Autorka d’alej uvádza príklad toho, ako stúpa percento zamestnaných žien s det'mi v Spojenom královstve Vel'kej Británie a Severného Írska:

[...] na jar 1998 bola miera pracujúcich žien s nezaopatrenými det'mi $61 \%$. Naopak, percento pracujúcich žien bez detí predstavovalo $75 \%$. Z hladiska veku detí pracujúcich žien prieskum ukázal, že vyššia miera ekonomickej činnosti bola zaznamenaná u žien s det'mi školského veku v porovnaní s det'mi predškolského veku. $\mathrm{V}$ poslednom desat'ročí sa podiel pracujúcich bezdetných žien nezmenil. Naopak, u žien s nezaopatrenými det'mi sa zvýšil zo $61 \%$ na $67 \%$, zatial' čo u žien s det'mi do 5 rokov bol nárast ešte výraznejší (zo $45 \%$ na 55 \%).

Dôsledkom vyššie uvedenej rastúcej natality a neustále sa zvyšujúcej podpory zamestnanosti matiek a ich vstup do pracovnej sféry je zvýšená potreba umiestnenia dietatáa v čase mimo vyučovania do formálnej starostlivosti zabezpečovanej štátom, čo dokazuje aj iniciatíva štátu napríklad prostredníctvom Národného projektu Rodina a práca ${ }^{4}(\mathrm{SR})$. Z vyššie uvedeného môžeme usudzovat', že záujem štátu o zabezpečovanie starostlivosti o deti vo vol'nom čase je motivovaný dopytom spoločnosti po týchto zariadeniach.

\section{Zariadenia výchovy vo vol'nom čase v USA a UK}

O zariadeniach, ktoré poskytujú starostlivost' o deti vo vol'nom čase, môžeme povedat', že vo všeobecnosti je ich hlavným cielom poskytnút' starostlivost' predovšetkým o deti školského veku.

I ked’ sa v poslednej dobe zvyšuje percento pracujúcich matiek (či už u nás alebo v zahraničí), starostlivost' o deti vo vol'nom čase je v istej miere limitovaná. V Spojenom královstve Vel'kej Británie a Severného Írska (d’alej už len UK) len niektoré školy (v priemere 1 z 8 škôl) poskytujú rozšírené

\footnotetext{
4 Pozri bližšie http://www.iazasi.gov.sk/sk/narodny-projekt-rodina-a-praca/ako-sa-zapojit3.
} 
mimoškolské služby, aj to s istým obmedzením (napr. len v niektoré školské dni či na čast' prázdnin; Plantenga \& Remery, 2013). Z toho dôvodu je v UK väčšina matiek zamestnaná len na čiastočný pracovný úväzok. V našom prostredí sme takúto formu limitovania nepostrehli v žiadnom školskom zariadení.

Rovnako ako u nás, aj v zahraničí vstupuje mimo štátu do tejto oblasti aj súkromný či cirkevný sektor. Avšak všetky typy takýchto zariadení sa musia opierat' o isté nariadenia a štandardy. Napríklad v UK sú to Minimálne štandardy pre dennú starostlivost'a stráženie detí do veku 12 rokov (The minimum standards for daycare and childminding for children under age 12), ktoré boli navrhnuté s cielom zabezpečit' rovnakú úroveň kvality týchto služieb vo všetkých typoch zariadení, a tiež zabezpečit' konzistentný regionálny prístup $\mathrm{k}$ registrácii a inšpekcii v týchto zariadeniach.

V USA mnoho štátov vyžaduje, aby programy, ktoré zabezpečujú starostlivost' o deti v čase mimo vyučovania v iných zariadeniach, ako sú školy alebo verejné rekreačné strediská, získali licenciu. Licenčné predpisy sa líšia v jednotlivých štátoch svojím obsahom a cielovým zameraním, určujú podmienky fyzického prostredia, určujú pomer medzi počtom zamestnancov a počtom detí v danom zariadení, maximálnu vel'kost' skupiny, kvalifikáciu pracovníkov, zdravotné a hygienické požiadavky či ponúkané činnosti. Niektoré štáty oslobodili tieto programy od získania licencií. Ide najmä o také programy, ktoré sú prevádzkované a monitorované inými verejnými alebo neziskovými agentúrami. Oslobodenie od licencie môže nastat' aj vtedy, ak programy, ktoré poskytujú starostlivost' o deti, fungujú obmedzený počet hodín týždenne (U. S. Department of health and human services, 2006).

Na Slovensku a v ČR vychádzajú tieto zariadenia z výchovného programu pre ŠKD (nadväzuje na školský vzdelávací program) a zo školního vzdělávacího programu pro školní družiny.

V nasledujúcom texte priblížime a charakterizujeme jednotlivé krajiny a základné kategórie, na ktoré sme sa pri komparácii školských zariadení zamerali.

\section{$3.1 U S A$}

Jednotlivé mimoškolské programy sa vel'mi odlišujú v cieloch či financovaní. Rozsiahly prieskum v USA uskutočnil v roku 1998 Fashola, ktorý preskúmal 34 programov. Pred samotnou analýzou týchto programov sa venoval najskôr objasneniu základnej terminológie, resp. objasneniu rôznych typov programov: 
Daycare programs: ide o programy, ktorých hlavným cielom nie sú vzdelávacie činnosti (i ked' niektoré sa môžu na ne prioritne zameriavat'), ale poskytovanie najmä oddychových a kultúrnych činností. Ide o zabezpečenie útočiska (z ang. safehaven) pre deti pracujúcich rodičov. Ide o „pravé programy“ po vyučovaní v tom zmysle, že poskytujú starostlivost' len $v$ poobedných hodinách v čase od 15.00-18.00. hod., nie v ranných hodinách (pred vyučovaním). Ich návštevnost' je limitovaná taktiež vekom detí, prioritne sa zameriavajú na deti od predškolského veku po tretí ročník. Personál, ktorý pôsobí v takejto forme starostlivosti musí byt' licencovaný (musí mat' osvedčenie s názvom Child development associate). ${ }^{5}$

After-school programs: tieto programy sa zameriavajú predovšetkým na žiakov od 5 do 18 rokov a poskytujú rôzne činnosti (vzdelávacie/záujmové). Na rozdiel od predchádzajúceho typu programu častokrát zabezpečujú aj prepravu detí do zariadení, v ktorých sa programy realizujú. Okrem toho sa odlišujú aj tým, že zamestnanci nemusia byt' nevyhnutne licencovaní. Taktiež ponúkajú širší výber oddychových činností a v priemere väčší počet dospelých zamestnancov na diet’a. Vo všeobecnosti možno povedat', že zabezpečujú kreatívne trávenie vol'ného času detí, ako aj príležitost' na rozvoj ich záujmov či talentu.

School-based academic extended-day programs: ide o programy, ktoré sú zvyčajne situované v budove školy a svojou činnostou priamo nadväzujú na vzdelávaciu činnost' v škole. Personálne obsadenie je tvorené najmä učitel'mi zo školy a asistentmi (plánujú a zabezpečujú oddychové a kultúrne činnosti). Úlohou učitel'ov je nadväzovat' na preberané učivo v škole a dozerat' na bezpečnost' detí. Okrem toho zaškol'ujú asistentov a dobrovol'níkov.

K uvedeným typom programov by sme zaradili ešte programy, ktoré poskytujú starostlivost' pred školským vyučovaním:

The school breakfast programs: ${ }^{6}$ predstavujú federálne podporované programy zamerané na stravovanie, ktoré sú v prevádzke vo verejných a neziskových

Child development associate je široko uznávané potvrdenie o absolvovaní vzdelávania, zameraného na rané detstvo. Ide o klúčový certifikát potrebný pre d’alší kariérny postup v tejto oblasti. Kurzy pripravujú študentov na prácu s det'mi (od dojčiat, cez batol’áá až po predškolákov) a zvyčajne sa zameriavajú na jazykový rozvoj, bezpečnost' detí, a pod.

6 Pilotný projekt k tomuto programu bol spustený roku 1966. V súčasnosti ho spravuje na federálnej úrovni štátny úrad Potravy a výživy, ktorý riadi Ministerstvo pol’nohospodárstva (USA). Na štátnej úrovni je program zvyčajne riadený štátnym vzdelávacím úradom, ktorý prevádzkuje program prostredníctvom dohôd s miestnymi orgánmi školských potravín vo viac ako 89000 školách a inštitúciách (United States Department of Agriculture, 2013). 
súkromných školách a internátnych zariadeniach. Školské okresy a nezávislé školy, ktoré sa rozhodnú participovat' v tomto programe, získajú finančné dotácie z Ministerstva pol'nohospodárstva (USDA) za každé jedlo, ktoré vydajú. Na oplátku však musia podávat' také raňajky, ktoré splňajú federálne požiadavky. Taktiež musia znížit' alebo celkom odpustit' poplatky za raňajky pre skupinu vybraných detí (napr. deti zo sociálne znevýhodneného prostredia).

Všetky programy však zdôrazňujú bezpečné prostredie, pozitívnu klímu a do svojho režimu dňa zarad'ujú vzdelávacie, oddychové a kultúrne činnosti. Fashola (1998) d’alej uvádza, že všetky programy sa zameriavajú nielen na vzdelávacie ciele, ale aj na oddychové a kultúrne činnosti. Ako sme už uviedli vyššie, obdobné činnosti nachádzame aj v režime dňa slovenských ŠKD a českých ŠD. Rovnako ako u nás, tak aj v zahraničí sa prostredníctvom týchto činností smeruje k rozvoju „celého diet’ata“ (Bronfenbrenner, 1986). Vychádzajúc z prieskumu zameraného na spokojnost' rodičov ohl'adne aktivít, realizovaných v týchto zariadeniach, môžeme povedat', že 8 z 10 rodičov vyzdvihuje ponuku najmä fyzických aktivít a 7 z 10 rodičov tvrdí, že tieto zariadenia ponúkajú pomoc pri písaní domácich úloh, desiatu a olovrant a miesto, kde deti môžu zlepšovat' svoje písanie a čítanie (Afterschool Alliance, 2014).

V správe America after 3pm (Afterschool Alliance, 2014) sa tiež spomína, že najväčším poskytovatelom mimoškolských programov pre deti sú verejné školy, následne cirkevné a iné zariadenia ako napr. Boys \& Girls Clubs, YMCAs, či súkromné školy.

Pracujúci rodičia detí do 13 rokov v USA si môžu uplatnit' daňovú úlavu, avšak len v rámci služieb starostlivosti o deti. Sem môžeme zaradit' programy po vyučovaní, ktoré dieta navštevuje v čase, kým je jeden z rodičov v práci. Na druhej strane sa však táto daňová úlava nevzt'ahuje na také programy, ako sú napr. skauting, Little League alebo podobné programy, ktoré sa prioritne nezameriavajú na stráženie detí (Mancini, 2015).

Ako sme už uviedli vyššie, aj v USA sa tieto zariadenia musia riadit' istými nariadeniami. Okrem spomenutých licencií si každý štát vytvára štandardy pre programy poskytujúce starostlivost' o deti vo vol'nom čase. Vo všeobecnosti môžeme povedat', že štandardy štátov v USA obsahujú približne rovnaké oblasti, ako sú napr. zdravie, bezpečnost' a výživa; vzt'ahy; program a činnosti; administrácia a pod. (podobne ako v štandardoch v UK). 
Z dôvodu federatívneho usporiadania USA sa zameriame len na jeden štát, konkrétne Michigan ${ }^{7}$. Štandardy sú dobrovol'né pre všetky programy, okrem tých, ktoré majú nariadené dodržiavat' a plnit' ich kvôli financovaniu. Štandardy sú však indikátorom vysokej kvality zariadenia a programy ich môžu využívat' na neustále zlepšovanie poskytovaných služieb (Michigan State Board of Education, 2008).

\subsection{Spojené královstvo Vel'kej Británie a Severného Írska}

Starostlivost' o deti v čase mimo vyučovania poskytujú vládne zariadenia, ktoré sú súčast'ou rozšíreného školského programu a zahŕňajú Afterschool clubs, Breakfast clubs a Holiday clubs alebo Playschemes. Hlavný rozdiel medzi uvedenými zariadeniami spočíva najmä v čase ich prevádzky, o čom napovedá už ich názov. Všetky tieto zariadenia by mali byt’ za normálnych okolností registrované na Úrade pre štandardy vo vzdelávaní (Ofsted: Office for Standards in Education, Children's Services and Skills). Úloha Ofsted-u je podobná ako poslanie našej školskej inšpekcie (Ofsted je zodpovedný napr. za kontrolu škôl a akadémií, niektorých nezávislých škôl, a mnoho d’alších vzdelávacích inštitúcií a programov okrem vysokoškolského vzdelávania, kontrolu starostlivosti o deti, za zverejňovanie správ o ich zisteniach na zlepšenie celkovej kvality vzdelávania a odbornej prípravy a pod.). Registrácia v Ofsted-e sa týka len zariadení v Anglicku. Ak sa klub nachádza v Škótsku, Walese alebo v Severnom Írsku, registruje sa na príslušnom úrade, napr. v Škótsku to je The Care Inspectorate (SCSWIS); vo Walese je to Care and Social Services Inspectorate Wales (CSSIW).

Registrácia v Ofsted-e je v závislosti od druhu zariadenia:

- dobrovol'ná - platí pre zariadenia, ktoré poskytujú starostlivost' pre deti menej ako 2 hodiny denne, alebo ktoré poskytujú starostlivost' pre deti vo veku od 8 do 18 rokov, alebo

- povinná ${ }^{8}$ - pre všetky ostatné zariadenia, ktoré poskytujú starostlivost' o deti (Out of schol alliance, 2015).

Ak sú tieto zariadenia priamou súčast’ou školy, tak spadajú pod jej registráciu, t.j. nemusia sa zaregistrovat' samostatne.

Michigan State Board of Education (2008).

8 Podmienky registrácie sú rôzne v závislosti od druhu zariadenia či veku a počtu detí, pre ktoré sú určené. $V$ našom príspevku sa zameriavame len na zariadenia pre deti v mladšom školskom veku. 
Breakfast clubs: nachádzajú sa spravidla v škole a ponúkajú det’om vo veku od 4 do 16 rokov priatel'ské a uvol'nené prostredie, kde si môžu vychutnat' svoje prvé jedlo dňa. Vo Vel'kej Británii sa začali objavovat' začiatkom 90. rokov 20. storočia a z roka na rok sú stále populárnejšie. V súčasnosti $85 \%$ škôl v UK má zriadené Raňajkové kluby (Kellogg's, 2014)..$^{9}$ Raňajkové kluby nemusia byt' registrované v Ofsted-e, pretože fungujú menej ako 2 hodiny denne. Zvyčajne sú otvorené od 7.30/8.00 hod. do začiatku vyučovania. Okrem raňajok ponúkajú rôzne činnosti zahrňujúce výtvarnú výchovu, rôzne zručnosti, hry a pod. (Walker, 1999). ŠD a ŠKD môžu (ako sme uviedli aj v rámci opisu mimoškolskej starostlivosti v USA, nezameriavajú sa na správnu výživu a podávanie hotových jedál) fungovat' aj ako „ranná družina“.

Afterschool clubs: ide o kluby, ktoré sa môžu situovat' na rôznych miestach (škola, mestské centrum, atd'.). Poskytujú rôzne druhy aktivít det'om vo veku od 4-16 rokov.

Činnosti poskytované v uvedených zariadeniach sú rôzne. Môžeme povedat', že variujú od zariadenia k zariadeniu, najmä v závislosti od ich typu. Napríklad Breakfast clubs poskytujú výživné raňajky a čas pre hranie a stretnutie sa s priatel'mi a spolužiakmi. Avšak pre všetky tieto zariadenia platí, že poskytujú bezpečné prostredie s vysokokvalitnou starostlivostou a škálou zábavných a stimulujúcich aktivít pre deti (Out of school alliance, 2015).

Z hladiska poskytovania starostlivosti o deti vo vol'nom čase môžeme hovorit' o formálnej (rôzne zariadenia, kluby, jasle a pod.) a neformálnej (starí rodičia, členovia rodiny, susedia a pod.) starostlivosti. Berúc do úvahy konštitučné usporiadanie UK (Škótsko, Anglicko, Wales a Severné Írsko) a rozsahové obmedzenia tohto príspevku, $v$ d’alšom texte sa zameriame len na jednu krajinu, a to Anglicko.

V roku 2011 využívalo takmer 78 \% všetkých rodín v Anglicku s det'mi pod 15 rokov niektorú z foriem starostlivosti o deti (Huskinson et al., 2013). Najčastejšie používanou formálnou starostlivost’ou sú Afterschool clubs (35\%), pričom viac ako $52 \%$ Breakfast clubs a $40 \%$ Afterschool clubs bolo prevádzkovaných školou (Brind et al., 2014).

Uvedená štúdia poskytuje aj percentuálne zastúpenie Raňajkových klubov (RK) v jednotlivých častiach UK - Škótsko a Severné Írsko sú regióny s najnižším percentom RK, kým Wales a North East predstavujú regióny s najvyšším percentom zriad'ovania RK. 
V neformálnej starostlivosti prevláda využívanie starostlivosti starých rodičov (26\%). V posledných rokoch sa zaznamenal aj nárast v počte poskytovatelov - v priebehu 2 rokov takmer o 3500 poskytovatelov (nárast od roku 2011 do 2013; Brind et al., 2014). Tento rastúci trend autori predpokladajú aj v d’alšom období.

Z hladiska veku detí vstupujúcich do týchto zariadení, Breakfast clubs a Afterschool clubs využívajú predovšetkým deti mladšieho školského veku. Percento návštevnosti oboch typov zariadení je približne rovnaké (Brind et al., 2014), takže môžeme predpokladat', že deti navštevujúce ranné kluby (32\%) prichádzajú do Afterschool clubs aj po vyučovaní (približne $36 \%$ ).

Cena za poskytovanie služieb spojených so starostlivostou o deti v čase mimo vyučovania je rôzna v závislosti od typu zariadenia: napríklad, v Afterschool clubs je to suma v priemere 22,03 libier za deň, v Holiday clubs 30,78 libier za deň. Navyše, pracujúci rodičia môžu získat' daňovú úlavu na pomoc pri platení nákladov na starostlivost' o deti: suma sa pohybuje okolo 122,50 libier na týždeň pre 1 diet’a, alebo 210 libier za 2 alebo viac detí (záleží na sume, ktorú rodičia zarobia). Ako sme uviedli vyššie, väčšina poskytovatelov starostlivosti o diet’a musí byt' registrovaná v Ofsted-e. To znamená, že musia spĺňat' minimálne normy a Ofsted ich kontroluje. Táto registrácia navyše umožňuje rodičom využívat' spomínané daňové úlavy pri platení poplatkov za starostlivost' o ich deti.

\section{$4 \quad$ Metodologické postupy a východiská}

V úvodnej časti sme opísali súčasnú situáciu a organizáciu ŠKD a ŠD na Slovensku a v ČR. Pri určení porovnávaných kategórií výskumnej vzorky sme brali do úvahy na prvý pohlad viditelné zhody medzi zariadeniami zvolených krajín. Vychádzame z konštitúcie našich zariadení výchovy vo vol'nom čase.

Okrem porovnania súčasných slovenských a českých školských zariadení sme sa zamerali aj na anglicky hovoriace krajiny (UK, USA). Z dôvodu zložitejšieho administratívno-územného členenia daných krajín, ktoré sa značne odlišuje od nášho priestoru, sme sa kvôli zabezpečeniu približne rovnakých podmienok pre každú krajinu rozhodli zamerat' na konkrétne štátne celky (UK - konštituentná krajina Anglicko, USA - štát Michigan). Pri výbere uvedených konkrétnych krajín (Anglicko a Michigan) bola pre nás rozhodujúca a smerodajná dostupnost' a kvantita verejne prístupných informácií. Z toho dôvodu možno považovat' náš výber za dostupný. 
Synchrónnemu porovnávaniu týchto zariadení predchádzala fáza získavania údajov prostredníctvom štúdia dokumentov jednotlivých krajín. Vo fáze kódovania sa ukazovali dominujúce podobné oblasti i niektoré špecifiká pre jednotlivé krajiny. Aby porovnávané zariadenia neboli heterogénne, vyberali sme informácie, ktoré $\mathrm{v}$ prvom čítaní ukazovali na podobnost' $\mathrm{s}$ našimi zariadeniami $\mathrm{v}$ nasledujúcich oblastiach: povaha vykonávaných a plánovaných činností (prípadne cielové zamerania aktivít), vekové rozpätie, poskytovatel', ustanovujúca legislatíva a kontrola ich spoločenského významu. Ked'že všetky kritériá nie sme schopní deduktívne dopredu určit', v našom príspevku sme použili tiež techniku otvoreného kódovania (por. Vlček, 2015).

Okrem vopred definovaných kategórií sa nám v priebehu štúdia dokumentov jednotlivých krajín vynorili d’alšie špecifické kategórie, ktoré sme následne zahrnuli do porovnávania uvedených zariadení, a to konkrétne maximálny počet detí v skupine, prípadne počet detí na jedného zamestnanca, finančná podpora rodiny zo strany štátu a výška rodičovských poplatkov na diet’a navštevujúce tieto zariadenia.

Ako uvádza Vlček (2015), pri zist'ovaní primárnych zdrojov informácií využitých v komparácii sa používa najmä pozorovanie, rozhovor, dotazník a obsahová analýza. $\mathrm{V}$ našom príspevku sme sa zamerali na poslednú $\mathrm{z}$ uvedených metód, a to obsahovú analýzu dokumentov. Pri výbere analyzovaných dokumentov sme sa opierali primárne o legislatívne a kurikulárne dokumenty zverejnené na oficiálnych internetových stránkach krajín, ako napr. stránky ministerstiev školstva jednotlivých štátov. Pri zbere relevantných informácií sme využívali aj prístupné databázy, v ktorých sme sa zamerali na vyhl'adávanie najnovších výskumov a príspevkov venujúcich sa nami riešenej problematike.

V štáte Michigan sme vychádzali predovšetkým zo vzorových štandardov pre volný čas a programy po vyučovaní, ktoré boli vytvorené Štátnou radou pre vzdelávanie štátu Michigan (2008) ${ }^{10}$. Dokument pracuje s termínom čas mimo vyučovania, pod ktorým sa rozumie čas pred a po vyučovaní, školské a letné prázdniny, či iný čas mimo vyučovania, a je primárne určený na pomoc školám a iným organizáciám, ktoré poskytujú komplexné programy pre žiakov základných a stredných škôl v čase mimo vyučovania.

10 Model Standards for Out-of-School Time After-School Programs in Michigan. Michigan State Board of Education. August 2008. 
Primárnym zdrojom informácií pri analýze krajiny Anglicko boli pre nás minimálne štandardy z roku 2012. Od poskytovatel'ov starostlivosti v čase mimo vyučovania sa očakáva ich dodržiavanie od septembra 2013. Okrem uvedeného zdroja sme opät' vychádzali z informácií získaných z oficiálnych webových stránok Ministerstva školstva (Department for Education).

\section{$5 \quad$ Porovnanie výchovných zariadení vo vybraných krajinách}

Školské programy sú určené na pomoc rodičom s ciel'om zladit' pracovné a rodinné povinnosti a zároveň poskytujú det'om podporu pri učení a širokú ponuku rôznych aktivít. V ČR a na Slovensku sa výchova v ŠD a ŠKD nechápe len ako sociálna služba, teda čas, v ktorom sú deti v bezpečí a po skončení vyučovania pod dozorom dospelej, odbornej osoby, kým rodičia pracujú. Výchova sa tu chápe ako „súčast' nutnej spoločenskej reprodukcie“ (Ministerstvo školství, mládeže a tělovýchovy ČR, 2002). ŠD a ŠKD svojím zaradením do sústavy výchovno-vzdelávacích zariadení majú svoje dominujúce postavenie vo výchove detí/žiakov s využívaním pedagogických princípov vol'ného času.

Pre sprehladnenie získaných informácií v jednotlivých krajinách sme vytvorili tabul'ku, v ktorej zobrazujeme hlavné porovnávané kategórie.

V tabul'ke 1 uvádzame niektoré kategórie, na ktoré sme sa pri komparácii školských zariadení v jednotlivých štátoch zamerali. Do tabul'ky sme nezahrnuli kategórie poskytovatel' a spoločenský význam, pretože nevystupujú ako špecifické znaky pre porovnávané krajiny. Spoločenský význam jednotlivých zariadení je charakterizovaný v dostupných dokumentoch a správach najmä ako podpora zamestnanosti žien, prípadne sa poukazuje na niektoré funkcie vol'ného času (Kratochvílová, 2010; Pávková, 2014). Poskytovatel' nakoniec nevystupuje ako porovnatel'ná kategória, ale ako kritérium výberu pre zariadenia v jednotlivých krajinách (poskytovatelom sú školy, štátom riadené inštitúcie). 


\section{Tabul'ka 1}

Vybrané kategórie porovnávaných krajín

\begin{tabular}{|c|c|c|c|c|}
\hline Krajina & SR & ČR & UK - Anglicko & USA - Michigan \\
\hline Vek & $6-15$ & $6-10$ & $4-16$ & $5-18$ \\
\hline Štandardy & $\begin{array}{l}\text { Výchovný } \\
\text { program }\end{array}$ & $\begin{array}{c}\text { Školní vzdělávací } \\
\text { program ŠD }\end{array}$ & $\begin{array}{l}\text { The minimum } \\
\text { standards for } \\
\text { daycare and } \\
\text { childminding for } \\
\text { children under } \\
\text { age } 12\end{array}$ & $\begin{array}{l}\text { Model standards } \\
\text { for out-of-school } \\
\text { time after-school } \\
\text { programs in } \\
\text { Michigan }\end{array}$ \\
\hline Obsah činnosti & $\begin{array}{c}\text { Oddychová } \\
\text { činnost', } \\
\text { pohybovo- } \\
\text { rekreačná } \\
\text { činnost', príprava } \\
\text { na vyučovanie }\end{array}$ & $\begin{array}{l}\text { Oddychová } \\
\text { činnost', } \\
\text { pohybovo- } \\
\text { rekreačná } \\
\text { činnost', príprava } \\
\text { na vyučovanie, } \\
\text { záujmová } \\
\text { činnost' }\end{array}$ & Neuvedené & $\begin{array}{c}\text { Vzdelávacia } \\
\text { činnost', } \\
\text { oddychová } \\
\text { činnost', kultúrna } \\
\text { činnost' }\end{array}$ \\
\hline Poplatky rodičov & $\begin{array}{c}\text { Určuje riaditel' } \\
\text { školy }^{11}\end{array}$ & $\begin{array}{c}\text { Určuje riaditel' } \\
\text { školy }^{12}\end{array}$ & $\begin{array}{c}\text { 22,03 libier/ } \\
\text { deňn }^{13}\end{array}$ & $\begin{array}{c}113.50 \text { dolárov/ } \\
\text { týždeň }^{14}\end{array}$ \\
\hline Počet/pomer & Neurčený15 & 30 & Neurčený' ${ }^{16}$ & 30 \\
\hline
\end{tabular}

\subsection{Vekové rozpätie}

Vo všeobecnosti môžeme povedat', že väčšina programov, resp. zariadení poskytujúcich starostlivost' o deti v čase mimo vyučovania, sa zameriava na vekovú skupinu dietata mladšieho školského veku. Vychádzajúc z vyššie uvádzaných správ (Brind et al., 2014; Afterschool Alliance, 2014) vekové zameranie týchto zariadení úzko súvisí s dopytom pracujúcich rodičov po nich. Podobná situácia je aj v slovenských a českých zariadeniach. Na druhej strane, rozdiel v poskytovaní starostlivosti z hl'adiska veku nachádzame aj v SR

11 Na jedného žiaka v sume neprevyšujúcej 7,5\% sumy životného minima pre nezaopatrené dietáa podla osobitného predpisu.

12 Výše úplaty se touto směrnicí stanovuje výše úplaty maximálně do $120 \%$ skutečných průměrných neinvestičních výdajů na žáka v předchozím kalendářním roce.

13 Poplatky sú rôzne pre rôzne zariadenia, uvádzame poplatok pre Afterschool clubs.

14 Uvedená je priemerná suma pre USA.

15 Počet detí v oddelení určí riaditel' ŠKD alebo riaditel' školy, ktorej je školský klub detí súčast'ou, pri dodržaní požiadaviek podla osobitného predpisu.

16 Určuje sa pomer pre rôzne zariadenia a podla veku detí - napr.: vek 3-7: 8:1; nad 8 rokov: $10: 1$. 
a ČR: v SR sa tieto zariadenia charakterom a činnost'ami orientujú predovšetkým na mladšś školský vek (i ked' legislatívne pokrývajú deti plniace povinnú školskú dochádzku v ZŠ). V ČR sa okrem detí mladšieho školského veku (ŠD) explicitne venujú aj žiakom druhého stupňa, pre ktorých zriad'ujú školské kluby detí. Podobnú situáciu nachádzame aj v zahraničí (UK, USA). V tomto smere môžeme povedat', že v SR neposkytujú školy starostlivost' o staršie deti (nad 11 rokov), respektíve neponúkajú pre ne atraktívne programy či krúžky, ktorými by ich prilákali. Táto skutočnost' bola SR vytknutá aj v správe Childcare services for school age children (Plantenga \& Remery, 2013).

\section{2 Štátne nariadenia a štandardy}

Podobnost' medzi krajinami nachádzame aj pri plnení požiadaviek kladených na školské zariadenia poskytujúce starostlivost' o deti vo vol'nom čase. V UK a USA je potrebné dodržiavat' národné štandardy, ktorými sa riadi celý chod daných zariadení. Dodržiavanie týchto štandardov je ukotvené v zákone: v UK to je The Children Act ${ }^{17}$. Avšak v USA sme nenašli priamo federálny zákon, týkajúci sa dodržiavania štandardov. Každý štát vo federácií si vytvára minimálne štandardy, ktoré schval'uje miestny úrad, napr. Board of the Health and Social Services Department.

V SR si ŠKD vypracovávajú výchovné programy, ktoré však neobsahujú presne také kategórie, ako nachádzame $\mathrm{v}$ štandardoch USA a UK (napr. požiadavky na poskytovanie stravy, požiadavky na priestorové a materiálne vybavenie a pod.). Vo výchovnom programe sú uvedené obsahové a výkonové štandardy jednotlivých tematických oblastí výchovy a ich rozplánovanie do režimu dňa ŠKD počas školského roka. Pri tvorbe výchovného programu (VP) vychádzajú vychovávatelia zo vzorového VP, ktorý je uverejnený na stránkach Ministerstva školstva, vedy, výskumu a športu SR.

V ČR sa pri tvorbe Školního vzdělávacího programu (ŠVP) vychádza z Metodiky tvorby ŠVP pro zájmové vzdělávání (vydal ho Národní institut dětí a mládeže v spolupráci s Ministerstvem školství mládeže a tělovýchovy - nie je však záväzný) a zo školského zákona, kde sú formulované povinné časti (napr. ciele, podmienky).

17 The Children Act 1989 guidance and regulations. Volume 2: careplanning, placement and casereview (Department for Education, 2015). 


\subsection{Obsah činnosti/ciel'}

Obsah činností v porovnávaných zariadeniach krajín je podobný, predovšetkým v ČR a SR, jediný rozdiel je len v zaradení záujmovej činnosti do režimu dňa - ako sme uviedli v prvej časti príspevku, táto činnost' je legislatívne vylúčená z činnosti ŠKD v SR od roku 2013.

Všetky školy v UK by mali poskytnút' služby zamerané na starostlivost' o deti mimo vyučovania (ak je po nich $\mathrm{v}$ danom regióne dopyt), a to bud' vo vlastných priestoroch, alebo v priestoroch v blízkosti školy, v čase od 8.00 hod. do 18.00 hod. Avšak nie všetky školy musia takéto služby ponúkat': v prípade, ak školy vedia preukázat', že $\mathrm{v}$ danom regióne je minimálny alebo žiadny dopyt po týchto službách, mali by verejnost' informovat' o d'alších miestnych službách podobného charakteru, napr. opatrovatelia v blízkosti školy (Out of School Alliance, 2015). Podobne sa zriad'ovatel' snaží reflektovat' potreby rodičov detí, ktoré navštevujú základnú školu v SR a ČR. Kluby tak pomerne flexibilne reagujú počtom oddelení na potreby rodičov. Ako sme už vyššie spomínali, väčšinou rozširovaním kapacity.

V USA fungujú rôzne zariadenia poskytujúce starostlivost' o deti vo vol'nom čase. Program s názvom School-based academic extended-day programs sa podobá na naše ŠKD a ŠD, pretože do denného režimu zarad'uje oddychové a kultúrne činnosti a prípravu na vyučovanie, čo je tradičné aj v československom prostredí. Naopak, programy The school breakfast program by sme mylne prirovnávali k našim „ranným družinám“. Tieto raňajkové kluby sa totiž primárne zameriavajú na zdravú výživu. Za spoločný znak možno pokladat' len raňajšiu starostlivost' o deti pred začatím školy.

V rámci denného režimu ŠD prebiehajú činnosti, podobne ako v ŠKD na Slovensku, ktoré sú zaradené do nasledujúcich skupín: odpočinkové činnosti, rekreačné činnosti, záujmové činnosti, príprava na vyučovanie. Tieto predpokladajú nielen pokojný odpočinok, ale aj pohybové činnosti (prednostne na čerstvom vzduchu). Podobne ako v ŠKD, tak aj v ŠD sú priebežne a podla potreby do režimu dňa zarad'ované (Pávková, 2014) aj sebaobslužné a spoločensky prospešné činnosti. $V$ nasledujúcom texte ozrejmíme rozdielne, príp. zhodné činnosti realizované v rámci režimu dňa v krajinách, ktoré sú predmetom nášho skúmania.

Vzdelávacie činnosti: cielom týchto činností je bud' zlepšit' výsledky žiakov v škole, alebo obohatit' obsah kurikula. Táto činnost' je totožná v našich 
podmienkach s prípravou na vyučovanie, ktorá vedie žiakov k pravidelnému plneniu si školských povinností, upevňuje vedomosti žiakov, utvára ich zručnosti a návyky, učí ich, ako sa majú správne učit'. Navyše, umožňuje žiakom vypracovat’ si písomné domáce úlohy. V USA sa na vzdelávacie činnosti najviac orientuje School-based academic extended-day programs, ktoré, ako sme už uviedli vyššie, sú zvyčajne situované v budove školy a svojou činnostou priamo nadväzujú na vzdelávaciu činnost' v škole. Konkrétne v štáte Michigan sú tieto vzdelávacie činnosti zamerané na podporu obsahu školského kurikula, ktoré sú bližšie uvedené v Model standards for out-of-school time after-school programs in Michigan (Michigan State Board of Education, 2008), môže íst' aj o vypracovávanie domácich úloh. Vo všeobecnosti v UK, ani v Anglicku, sme žiadny detailnejší opis charakteru vzdelávacích a d'alších činností nepostrehli. Dokonca ani v minimálnych štandardoch týkajúcich sa starostlivosti o deti v čase mimo vyučovania nie sú uvedené ani bližšie charakterizované činnosti tvoriace režim dňa vol'nočasových zariadení.

Zaujímavé je, že aj napriek tomu, že ako na Slovensku, tak aj v ČR sa v rámci mimoškolskej činnosti realizuje aj príprava na vyučovanie, ktorá nie je povinnou súčast'ou denného režimu. V ČR je v Metodickom pokyne (Ministerstvo školství, mládeže a tělovýchovy ČR, 2002) uvedené, že vychovávatel'ka domáce úlohy neopravuje, len upozorní či vyzve žiaka, aby chybu našiel. Vychádzajúc z toho, že mnohí rodičia považujú ŠD za zariadenie na opateru ich detí, kým sú v práci, je pravdepodobné, že budú podporovat' vypracovanie domácich úloh v ŠD. Rovnako to funguje aj na Slovensku, kde si žiaci po dohode vychovávatel'ky a rodiča vypracovávajú domáce úlohy. Za ich správnost' však zodpovedá rodič ako zákonný zástupca dietáata. Vychovávatel'ka nie je zodpovedná za vypracovanie domácich úloh, pretože takáto činnost' nie je v ČR ani na Slovensku - povinnou. Podporuje sa tak reálna domáca príprava žiakov s rodičmi tak, aby kompetencie rodičov nepreberala ŠD či ŠKD.

Oddychové činnosti: prostredníctvom týchto činností sa programy snažia viest' deti k športovej aktivite. Rovnako im poskytujú príležitost' rozvinút' ich talent a nadanie v oblasti, ktorá je pre nich zaujímavá (tanec, rôzne loptové hry, ručné práce a pod). V USA zameranie týchto činností podlieha záujmom a preferenciám diet'at'a (Fashola, 1998). V Michigane má mat' každé dieta príležitost' strávit' minimálne 30 minút fyzickými aktivitami v priebehu každých 3 hodín. pobytu v zariadení (Michigan State Board of Education, 2008). 
V slovenských ŠKD a českých ŠD sa stretávame s pohybovo-rekreačnými činnost'ami, ktoré sa vyznačujú výraznou pohybovou aktivitou (zvyčajne na čerstvom vzduchu - na školskom dvore). Môžu mat' podobu rozličnej pohybovej činnosti, športovej alebo manuálnej činnosti. Naopak, oddychové činnosti v našom prostredí sa vyznačujú pokojným charakterom, bez zvýšenej mentálnej či fyzickej činnosti detí. V UK a rovnako aj v Anglicku nevieme charakter týchto činností presne definovat', nakol'ko ani v minimálnych štandardoch nenachádzame konkrétne vymedzenie týchto činností.

Kultúrne činnosti: podobne ako predošlý typ činnosti, aj tieto podporujú rozvoj klúčových schopností a zručností. V USA do tejto skupiny zarad'ujú najmä také činnosti, ktoré podporujú rozvoj záujmov žiakov, ako napr. vyšívanie, pletenie, hra na gitare, stolové hry a pod. V Michigane Modelové štandardy uvádzajú činnosti, ktoré vychádzajú zo záujmu detí a nie sú súčastou štandardného školského dňa (vyučovania). U nás sú tieto činnosti totožné s oddychovou, ale i pohybovo-rekreačnou činnost'ou, v ČR najmä so záujmovou činnostou. Pre UK, Anglicko, aj v tomto prípade platí to isté, čo sme uvádzali pri ostaných činnostiach vyššie.

\subsection{Poplatky rodičov a maximálny počet detí v skupine}

Poplatky v žiadnej z porovnávaných krajín nie sú presne stanovené, ich výšku určuje zvyčajne zriad'ovatel' zariadenia. Rovnako ako poplatky, tak aj počet detí v skupine varíruje v závislosti od krajiny a veku diet'at'a. Na Slovensku v súčasnosti určuje počet detí vo výchovnom oddelení ŠKD riaditel’ školy, v ČR a USA je stanovený maximálny počet detí v skupine na 30 . V UK sa zvyčajne určuje pomer jedného pracovníka na určitý počet detí podla ich veku - tento pomer je však značne nižší ako v ostatných porovnávaných krajinách.

\section{Záver}

Cielom nášho príspevku bolo porovnat' zariadenia poskytujúce starostlivost' o deti v čase mimo vyučovania vo vybraných krajinách s českými ŠD a slovenskými ŠKD, pričom sme sa sústredili aj na objasnenie podobností i špecifík jednotlivých zariadení. Zamerali sme sa na anglicky hovoriace krajiny, v ktorých je povaha pedagogiky vol'ného času trochu iná, ako v našom česko-slovenskom prostredí, ktoré bolo ovplyvňované aj nemeckou Freizeitwissenschaft a Freizeitpaedagogik (Kaplánek, 2010; Bauman, 2012). Práve preto si myslíme, že $\mathrm{v}$ charaktere a organizácii týchto zariadení v porovnávaných krajinách by sa mohli nájst' nové inšpirácie. 
Problematiku ŠD a ŠKD považujeme za jednu z dôležitých tém samotnej pedagogiky vol'ného času. Skúmaniu na tomto poli sa však nedostáva dostatok pozornosti, možno práve preto, že tieto zariadenia sú v našom prostredí naozaj „tradičné“, usmerňované štátom i zriad'ovatel'om a rodičia či široká verejnost' ich legitimitu nespochybňujú. Na spoločenský význam týchto zariadení sme už vyššie poukázali aj z pohladu matiek, ktoré tak majú priestor a čas na nástup do zamestnania (aj napriek tomu, že v UK sa podporujú najmä matky pracujúce na čiastočný úväzok). Starí rodičia, ktorí zastrešovali výchovu vnúčat po vyučovaní, sú v súčasnosti ešte stále pracujúci, preto je najmä v našom prostredí dominantné postavenie školských výchovno-vzdelávacích zariadení. Poskytujú rodičom starostlivost' o deti najčastejšie priamo v danej škole kvalifikovanými pracovníkmi.

Na základe zistení v porovnaní fungujúcich zariadení v jednotlivých krajinách (najmä USA a UK) môžeme povedat', že slovenské ŠKD a české ŠD poskytujú komplexnú starostlivost' o deti realizovanú $v$ jednom spoločnom priestore, pričom v USA a UK existuje viacero zariadení a programov zameraných na konkrétne činnosti. Môžeme konštatovat', že naše ŠKD a české ŠD sú v porovnaní s vybranými krajinami (USA - Michigan, UK - Anglicko) z hladiska organizácie praktickejšie a časovo i priestorovo úspornejšie.

Pre všetky zariadenia je charakteristické, že deklarujú bezpečnú starostlivost' o deti. Vymykajú sa tak postupom a obsahom, ktoré dominujú v západnej Európe, akými sú kultúrna či sociálna animácia. Rámcovanie obsahu a činností môžeme vidiet' z vyššie uvedených anglicky hovoriacich krajín len v USA - Michigane, kde dochádza k diferenciácii činností podla ich cielového zamerania (doučovanie, oddychové činnosti, pohybové činnosti atd'.). Naopak v UK (ani v Anglicku) takéto rámcovanie obsahu ani činností nenachádzame.

Z nášho porovnania vychádzajú i niektoré inšpirácie pre naše prostredie, možno aj pre pedagogiku vol'ného času samotnú. Napríklad sú vhodnou inšpiráciou v zahraničí spomínané raňajkové kluby. Do našich škôl už prichádzali rôzne projekty zdravej výživy (dni jablka, mliečne automaty a pod.), ale smerovat' deti k pravidelnému a zdravému stravovaniu vo forme raňajok sa našim ŠD a ŠKD ešte nepodarilo. V tomto smere nachádzame inšpiráciu v systémovej spolupráci ŠD a ŠKD so školskými jedálňami, nakol'ko oba typy zariadení (ŠD, ŠKD) fungujú už v skorých ranných hodinách. Myslíme si, že takáto spolupráca by bola vítaná najmä zo strany pracujúcich rodičov, ktorých počty (predovšetkým pracujúcich matiek) narastajú v dôsledku zvyšujúcej sa podpory ich zamestnanosti. 
V určitých náznakoch si môžeme všimnút', že vzdelávacie činnosti a činnosti spomínaných zahraničných zariadení sa zameriavajú na doučovanie, d’alšie rozširovanie vedomostí (ako dôsledok mimoškolskej výchovy orientovanej na výkon). Samozrejme, vzdelávacie činnosti v ŠD a ŠKD majú aj iné podoby.

Ďalšou inšpiráciou je aj zameranie jednotlivých zariadení na vyššie vekové skupiny. USA, UK aj ČR poskytujú starostlivost' pre deti často až do 18 rokov, pričom na Slovensku ŠKD maximálne do 5. ročníka ZŠ (t.j. 11 rokov).

Podnetné je obmedzenie počtu detí v UK v týchto zariadeniach na jedného zamestnanca podla veku. Naopak, USA a ČR majú presne stanovený maximálny počet detí legislatívne, prípadne v štandardoch. Na Slovensku počet detí v oddelení ŠKD určuje riaditel' školy, no konkrétne obmedzenia nie sú stanovené.

Na záver musíme však konštatovat', že v zahraničí (najmä v anglicky hovoriacich krajinách) sa rozmáha aj súkromný sektor poskytovania starostlivosti mimo vyučovania. $V$ rámci d'alších otázok a oblastí, ktoré naše porovnanie prináša, by bolo zaujímavé zistit’ finančné náklady na štátne (školské) a súkromné zariadenia pre rodičov. Otázkou je aj to, či by rodičia preferovali skôr kvalitu daných zariadení v našom prostredí (či by rovnako aj u nás došlo k rozmachu súkromného sektoru), alebo bezpečnost’ a nízke poplatky za starostlivost'.

Ďalšou otázkou, ktorú výskum otvára, je preskúmanie konkrétnych metód a foriem realizovaných $\mathrm{v}$ UK a USA, ktoré $\mathrm{v}$ modelových či minimálnych štandardoch oboch krajín zostávajú vo všeobecnej rovine.

\section{Literatúra}

Afterschool Alliance. (2014). America After 3PM and the African-American community. Dostupné $\mathrm{z}$ http://afterschoolalliance.org/documents/AA3PM-2014/African.American-AA3PM2014-Fact-Sheet.pdf

Barnet Council. (2015). Breakfast, afterschool and holidayclubs. Dostupné z https://www. barnet.gov.uk/citizen-home/children-young-people-and-families/childcare/breakfastafter-school-and-holiday-clubs.html

Bauman, P. (2012). Současné podoby pedagogiky volného času. Pedagogika, 62(4), 404-425.

Brind, R., McGinigal, S., Lewis, J., Ghezelayagh, S., Ransom, H., Robson, J., ... Renton, Z. (2014). Childcare and early years providers survey 2013. Dostupné z https://www.gov.uk/ government/uploads/system/uploads/attachment_data/file/355075/SFR33_2014_ Main_report.pdf 
Bronfenbrenner, U. (1986). Alienation and the four worlds of childhood. The Phi Delta Kappan, 67(6), 432-436.

Callender, C. (2000). The barriers to childcare provision. London: Department for Education and Employment.

Dedeková, N., Vaňková, I., Macko, A., \& Mesiar, A. (1960). Niektoré výchovno-vzdelávacie otázky $v$ družinách mládeže. Bratislava: Slovenské pedagogické nakladatel'stvo.

Department for Education. (2015). The Children Act 1989 guidance and regulations. Volume 2: careplanning, placement and case review. Dostupné z https://www.gov.uk/government/ uploads/system/uploads/attachment_data/file/441643/Children_Act_Guidance_2015. pdf

Fashola, O. S. (1998). Review of extended-day and after-school programs and their effectiveness. Report No. 24. Baltimore: Johns Hopkins University, Center for research on the education of students.

Huskinson, T., Pye, J., Medien, K., Dobie, S., Ferguson, C., Gardner, C., ... D’Souza, J. (2013). Childcare and early years survey of parents 2011. SFR08/2013. London: Department for Education.

Kaplánek, M. (2010). Pedagogika volného času - projekt budoucnosti, nebo slepá ulička? Pedagogika, 60(1), 12-20.

Kellogg's. (2014). An audit of school breakfastclub provision in the UK. Dostupné $\mathrm{z}$ http:// www.kelloggs.co.uk/content/dam/newton/images/masterbrand/UK/R5_Kelloggs\%20 Breakfast\%20Club\%20Audit\%20APSE.pdf

Kratochvílová, E. (2010). Pedagogika volného času. Výchova $v$ čase mimo vyučovania $v$ pedagogickej teórii a praxi. Trnava: Typi Universitatis Tyrnaviensis.

Mancini, J. (2015). Do After-school programs count toward child-care taxcredit? Dostupné z http:// finance.zacks.com/afterschool-programs-count-toward-childcare-tax-credit-2403.html

Michigan State Board of Education. (2008). Model standards for out-of-school time after-school programs in Michigan. Dostupné z https://www.michigan.gov/mde/0,4615,7-140-5373-$-, 00 . \mathrm{html}$

Ministerstvo školstva, vedy, výskumu a športu SR. (2009). Vyhláška MŠ SR č. 306/2009 Z.z. o školskom klube detí, školskom stredisku záujmovej činnosti, centre vol'ného času, školskom hospodárstve a stredisku odbornej praxe. Dostupné z https://www.minedu.sk/data/ att/654.pdf

Ministerstvo školství, mládeže a tělovýchovy ČR. (2002). Metodický pokyn k postavení, organizaci a činnosti školních družin. Dostupné z http://www.msmt.cz/mladez/metodicky-pokyn-kpostaveni-organizaci-a-cinnosti-skolnich-druzin

Ministerstvo školství, mládeže a tělovýchovy ČR. (2004). Zákon č. 561/2004 Sb., o předškolním, základním, středním, vyššímodbornémajiném vzdělávání(školskýzákon).Dostupnézhttps:// portal.gov.cz/app/zakony/zakon.jsp?page=0\&nr=561 2F2004\&rpp=15\#seznam

Ministerstvo školství, mládeže a tělovýchovy ČR. (2005). Vyhláška č.74/2005 Sb., O zájmovém vzdělávání. Dostupné z http://www.msmt.cz/dokumenty/vyhlaska-c-74-2005-sb-1

Ministerstvo vnútra Slovenskej republiky. (2008). Zbierka zákonov č. 265/2008. Vyhláška Ministerstva vnútra Slovenskej republiky. (2008). Dostupné z https://www.nbs.sk/_img/ Documents/ZAKLNBS/LEGISLAT/euro/ev2008-265-mvsr.pdf

Out of school alliance. (2015). Help and support for out of schol clubs. Dostupné z http://www. outofschoolalliance.co.uk/ 
Pávková, J. (2014). Pedagogika volného času. Praha: UK, Pedagogická fakulta.

Pávková, J., Hájek, B., Hofbauer, B., Hrdličková, V., \& Pavlíková, A. (2008). Pedagogika volného času: teorie, praxe a perspektivy výchovy mimo vyučovaní a zařízení volného času. Praha: Portál.

Plantenega, J., \& Remery, C. (2013). Childcare services for schoolage children. A comparative review of 33 countries. Dostupné z https://www.qld.gov.au/families/education/pages/ care.html

Podešva, B. (1952). Práca v družinách mládeže: príručka pre vychovávatel'ky. Bratislava: Štátne nakladatel'stvo.

Smith, F., \& Barker, J. (2000). Child-centred afterschool and holiday childcare. Children 5-16. Research briefing 10. Hull: Economic and social research council.

Štátna školská inšpekcia (2015). Správa o stave zabezpečenia podmienok a priebehu výchovnovzdelávacej činnosti v školskom klube detí v školskom roku 2014/2015 v SR. Bratislava: ŠŠI SR. Dostupné z https://www.ssiba.sk/admin/fckeditor/editor/userfiles/file/Dokumenty/ SPRAVY/2015/181_TI_SKD_SR_45.pdf

U.S. Department of health and human services. (2006). Promoting quality in afterschool programs through state childcare regulations. Dostupné z http://www.researchconnections.org/ childcare/resources/11434/pdf

U. S. Office of personnel management. (2015). Child care/Out of school. Dostupné z https://www. opm.gov/policy-data-oversight/worklife/reference-materials/child-careout-of-school/

United States Department of agriculture. (2013). Food and nutrition service. The school breakfast program. Dostupné z http://www.fns.usda.gov/sites/default/files/SBPfactsheet.pdf

Velikanič, J. (1958). Mimotriedne zamestnanie v 1. postupovom ročníku všeobecnovzdelávacej školy. Príručka pre učitelov 1. Postupného ročníka. Bratislava: Slovenské pedagogické nakladatel'stvo.

Vlček, P. (2015). Srovnávací výzkum v pedagogice - některé úvahy o metodologii problémového př́stupu. Pedagogická orientace, 25(3), 394-412.

Walker, M. (1999). Out-of-school breakfastclubs: The solution for parents and children. In N. Donovan \& C. Street (Eds.), Fit for schol. How breakfast clubs meet health, education and childcare needs (s. 18-23). London: New Policy Institute.

\section{Autorky}

Mgr. Michaela Minárechová, PhD., Katedra školskej pedagogiky, Pedagogická fakulta TU, Trnava, Priemyselná 4, P.O.BOX 9, 91843 Trnava, SR, e-mail: michaela.minarechova@truni.sk

Mgr. Zuzana Bánovčanová, PhD., Katedra školskej pedagogiky, Pedagogická fakulta TU, Trnava, Priemyselná 4, P.O.BOX 9, 91843 Trnava, SR, e-mail: zuzana.banovcanova@truni.sk 


\title{
Comparison of Slovak and Czech school clubs with selected countries
}

\begin{abstract}
This article partly reflects the issues of leisure education. This is a part of pedagogy which still has not been precisely defined and clarified. The main purpose of this paper is to describe the basic features of facilities that are engaged in childcare out of school hours. The paper also focuses on the comparison between our facilities (Czech and Slovak out-of-school time facilities) and similar facilities in English speaking countries (USA, UK). In the next part of this paper we focus on clarification and comparison between out-of-school time facilities in selected countries (UK - England, USA - Michigan) and Slovak and Czech facilities (activities, time and spatial organization). Furthermore we also focus on regulations and requirements for these facilities by particular states. Although there are minor variations between these facilities we can state that its importance has a society-wide character. In our environment, we consider the compared school facilities for more complex and more practical childcare out of school hours. On the other hand, in foreign countries (like USA and UK) private sector is more visible in the area of leisure education and in similar facilities of childcare out of school hours.
\end{abstract}

Key words: comparison, after-school care centres, after-school clubs, childcare after school

Pospíšilová, H., \& Komínková, L. (2015). Svět školní družiny. Olomouc: Univerzita Palackého v Olomouci.

Školní družina je tradičním školským zařízením, které dětem nabízí širokou paletu činností. Autorky v knize předkládají výsledky dlouhodobého výzkumného šetření realizovaného $\mathrm{v}$ prostředí školní družiny. Prostřednictvím etnografického zkoumání přináší kniha netradiční úhel pohledu na školní družinu, kde jsou zobrazeny ústřední znaky chodu školní družiny ve spojitosti s jejími hlavními aktéry - dětmi a vychovatelkami. Čtenáři dostávají možnost zamyslet se nad klíčovými momenty každodenní reality školní družiny v oblasti organizačních a materiálních podmínek i činností ve školní družině. Kniha zároveň nabízí vhled do charakteristik a dynamiky dětských kolektivů, kolektivu vychovatelek s přesahem k vedení školy. 